\title{
低層集合住宅地の街並み景観に対する居住者の 認識構造に関する研究
}

\author{
久 保 貞*, 上甫木 昭春*, 安 部 大 就* \\ 中 瀬 勲*, 伊藤康 則*, 和田昭 太* $^{*}$
}

The Structural Analysis to the Landscape Cognition of Resident in Low rise housing area

Tadashi KUBO, Akiharu KAMIHOGI, Daishu ABE, Isao NAKASE, Yasunori ITO, Shota WADA

\begin{abstract}
摘要：低層集合住宅地において，良好な街亚み景観を創出するためには，街亚み景観に対する居住者の認識構造を 把握する必要がある。本研究では, 低層集合住宅地の街並み景観に对する居住者の認識構造を, 情緒的語句 (形容詞 对)による意味構造の把握拉よび街並み景観を構成する諸要素に対する認識構造の把握の両面から検討し,さらに两 者の関連性を明らかにした。
\end{abstract}

1. はじめに

低層集合住宅地のいわゆる良好な“全体環境”を䁔成 するためには, 住環境・街並み景観注1) ・外部空間構成の 各ステージにおりる居住者の反応行動を把握することが 必要である。先に発表した「低層集合住宅地の景観計画 に関する研究」（造園雑誌 VOL. 46, No. 5)では, 住環境 に対する認識構造とそれに係わる住宅地属性について考 察した。本研究では, 低層集合住宅地の街並み景観に対 する居住者の認識構造を把握することを目的とした。街 並み景観に対する居住者の認識構造をとらえるには, 街並 み景観を構成する諸要素に対する居住者の認識構造と街 並み景観の意味構造の考察が必要であると考える。すな わち, 居住者の街並み景観に対する評価は, 街並み景観 を構成する諸要素に対する認識過程を通じての全体的意 味構造として理解できると考える。

本研究では, まず情緒的語句（形容詞対）を評定尺度 として S.D. 法により街並み景観を意味的に把握した。 次に街並み景観を構成する物理的環境構成要素（以下景 観構成要素と呼ぶ）に対する認識構造を把握した。さら に街並み景観の意味構造と景観構成要素との関連性につ いて考察し，低層集合住宅地の良好な街並み景観の創出 における住み手側からの示唆を得た。

\section{2. 調查概要}

本研究で対象とした低層集合住宅地は 6 住宅地であり, 6 住宅地の選出にあたっては, 実態調查 2 した23住宅地 の中から, 地域性, 建設年次, 地形タイプ, 住棟配置形
式等を考虑して選出した。

調查は，6住宅地とあ全戸を対象として昭和57年 7 月 に直接面接法で行ない, 数回訪問して不在の場合は留置 法で行なった。調查に用いた情緒的語句及び景観構成要 素は, 実態調查を踏まえ調查員によるブレーンストーミ ングにより設定した（図ー $1 ， 2$ 参照）。情緒的語句及 び景観構成要素の評価ランクは, 図ー $1 ， 2$ 亿示すよう に 5 段階に分けた。

調查対象住宅地の概要は以下の如くである。

・庭代台タウンハウス（N I）－ 傾斜地を利用した並 列配置のタウンハウスで, 緑が豊かで成熟した住宅地の 㞣囲気が感じられる。

・桃山台タウンハウス（MO）－ 並列配置のタウンハ ウスで, 中央にゅるやかな $\mathrm{S}$ 字カーブの園路が通るすっ きりした芝生地の共用庭を持ち, 専用庭の植栽や建物と とあに落ち着いた雾囲気を生み出している。

・サニータウン長野台（NA）－丘陵地に立地し, 豊 かな緑を背景とした明るく開放的な雾囲気のタウンハウ スである。

・名谷16団地 (MY) - 住棟配置・建物のデザインが 変化に富むが，共用庭は規模が小さく平凡な感じがする。 各戸駐車による通路の入り込みが目ざわりである。

- 山田西 A団地 (Y A ) - 住棟配置・建物の形の変化 等により多様なスカイラインを呈している。また共用庭 あフォーマルな形で堅い仕上げになっており，全体的に アーバニティの高さが感じられる。

・名谷28団地 $(M I)-$ 明るく, 落ちついた雾囲気の 


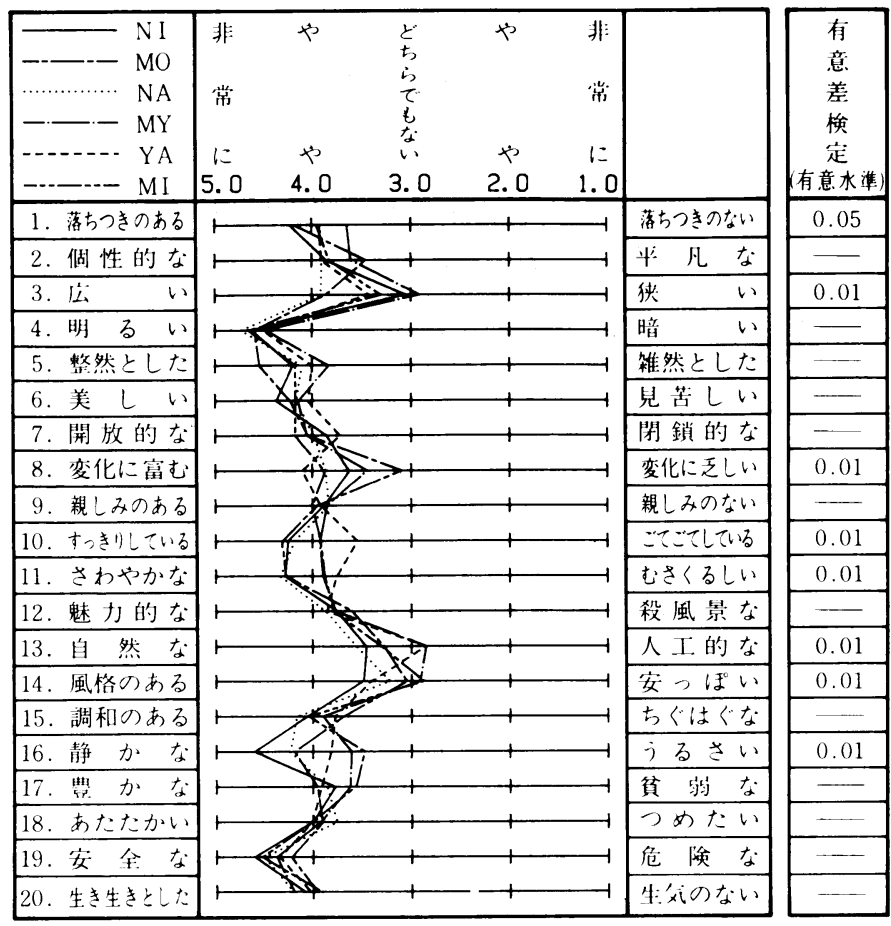

図ー1情緒的語句に対する反応傾向及ひ住宅地間での有意差検定

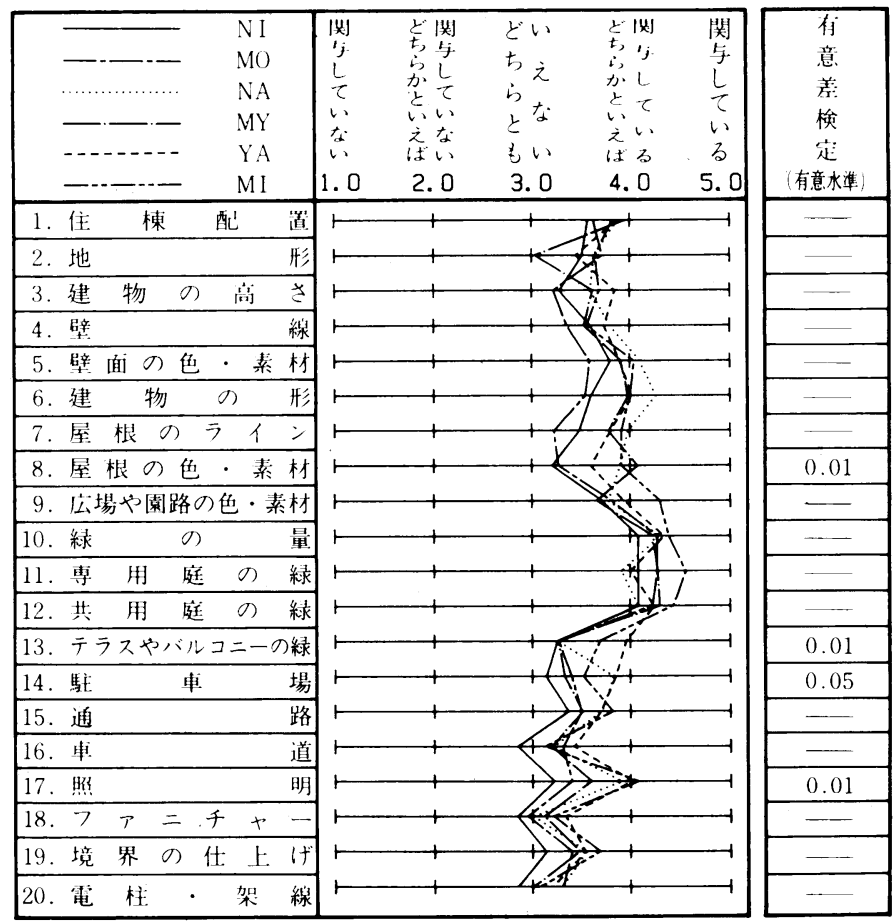

図ー2 景観構成要素の関与度及ひ住宅地間での有意差検定
するアーバニティの高いタウンハ ウスである。

共用庭は, 地形の高低差を利用し た空間の多重利用, 電柱の地下埋 設等により多様で質の高い空間と なっている。

なお, 調查対象住宅地の有効サ ンプル数は, 庭代台タウンハウス -35戸(88\%)，桃山台タウンハウ スー22戸 $(76 \%)$, サニータウン長 野台 -60 戸 $(86 \%)$, 名谷 16 団地一 56 戸 (78\%), 山田西 A団地一 70 戸 (83\%), 名谷28団地一23戸(68\%) である。

\section{3. 街並み景観の意味構造}

ここでは, 街並み景観の全体的 な雾囲気について，情緒的語句を 評定尺度として分析した意味構造 について述べる。

（1）情緒的語句倿対する反応傾向 及び住宅地間での有意差検定

図-1は，情緒的語句に対する 住宅地別の平均評価值と分散分析 による 6 住宅地間での有意差検定 結果を示したあのである。まず情 緒的語句付対する反応傾向をみる 之, 6 住宅地とも平均評価値が約 3.0 以上で全体的にポジィティブ な反応を示している。てのてとは, 低層集合住宅地の街並み景観が居 住者に比較的良好な状態として受 け止められているてとを示すすの といえる。6 住宅地とも平均評価 值が 4.0 以上の情緒的語句をみる と, 低層集合住宅地の街並み景観 は, “明るい” “美しい”“安全 な”等のイメージが強いといえる。 住宅地別にみると上記の共通的な イメージに加えて, 庭代台タウン ハウス（N I）は“静かな”、桃 山台タウンハウス（MO）は“整 然としだ 住宅地であるといった 特性を持っているといえる。

次に情緒的語句に対する住宅間 での有意差検定結果をみると, 相 対的に評価の高い“美しい一見苦 しい”，“明るい一暗い”，“安 
全なー危険な”等の情緒的語句は, 住宅地間で有意な差 はない。一方, 相対的に評価の低い“自然な一人工的な”

“風格のある一安っぽい”等では有意差がみられ, 建設 年次の古い庭代台タウンハウス（N I ) では両語句とも 比較的評価が高くなっている。また住宅地間での有意差 は, 20 対の情緒的語句の中で 8 対にみられ，乙のてとは 各住宅地の情緒的意味からの固有性を示唆している。

\section{（2）情緒的語句からみた街並み景観の意味構造}

図一 3 は，情緒的語句に対する反応デー夕を直接バリ マックス法により解析し, 住宅地別の情緒的語句のグル ープを総合的に表現したものである。情緒的語句のグル ープは, 各住宅地とあ第 3 合成変量までについて, 同一 合成变量の構造ベクトルの要素で絶対値 0.55 以上の情 緒的語句により成立している。ててで各住宅地での第 3 合成変量までの累積寄与率は, 40 50\%前後 (N I -47 $\%, \mathrm{MO}-56 \%, \mathrm{NA}-37 \%, \mathrm{MY}-43 \%, \mathrm{YA}-37 \%$, M I -49\%) である注2) なお, 各住宅地とあ第 1 〜第 3 合成変量の固有值は 1.0 以上である。

図一 3 亿示す情緒的語句に対する居住者の認識構造を みると，“変化富む一変化に乏しい”，“個性的な一 平凡な”，“魅力的な一殺風景な”，“豊かな一貧弱な” 等が「魅力性」に係わるグループとして認識できる。ま た“あたたかい一つめたい”，“親しみのある一親しみ のない”，“落ちつきのある一落ちつきのない” 等が

「親密性」に係わるグループとして, “すっきりしてい るーでてでてしている”，“さわやかなーむさくるしい"
“整然とした一雑然としだ 等が「整然性」に係わるグ ループとして認識できる。すなわち，「魅力性」，「親 密性」,「整然性」の 3 軸は, 低層集合住宅地の街並み 景観の意味構造を理解する上で重要な軸といえる。住宅 地別に情緒的語句に対する居住者の認識構造をみると, 桃山台タウンハウス（MO）では「安堵性」, サニータ ウン長野台（N A）では「開放性」が住宅地の個有性を 意味する軸として認識できる。また山田西 A団地 (YA) と名谷28団地（M I ）では，“豊かな一貧弱な”之関連 して，それぞれ「親密性」の軸（Y A），“さわやかな 一むさくるしい”と“風格のある一安っぽい”（M I) 等が同一グループを形成していることが特徴である。

\section{4. 街並み景観に対する景観構成要素の関与度及ひ認 識構造}

ここでは, 居住者の街並み景観に対する影観構成要素 の関与度及び認識構造について述べる。

(1) 景観構成要素の関与度及び住宅地間での有意差検定

図一 2 は，住宅地別に景観構成要素に対する平均評価 値と分散分析による住宅地間での有意差検定結果を示し たあのである。まず街並み景観に対する景観構成要素の 関与度の全体的傾向は, 平均評価值が約 3.0 以上で "関 与している”に片寄った傾向を示している。てのととは, 関与度の程度の差はあれ, 居住者はてれらの景観構成要 素が街並み景観に関与しているという認識を持っている ことを示している。景観構成要素別に関与度をみると，

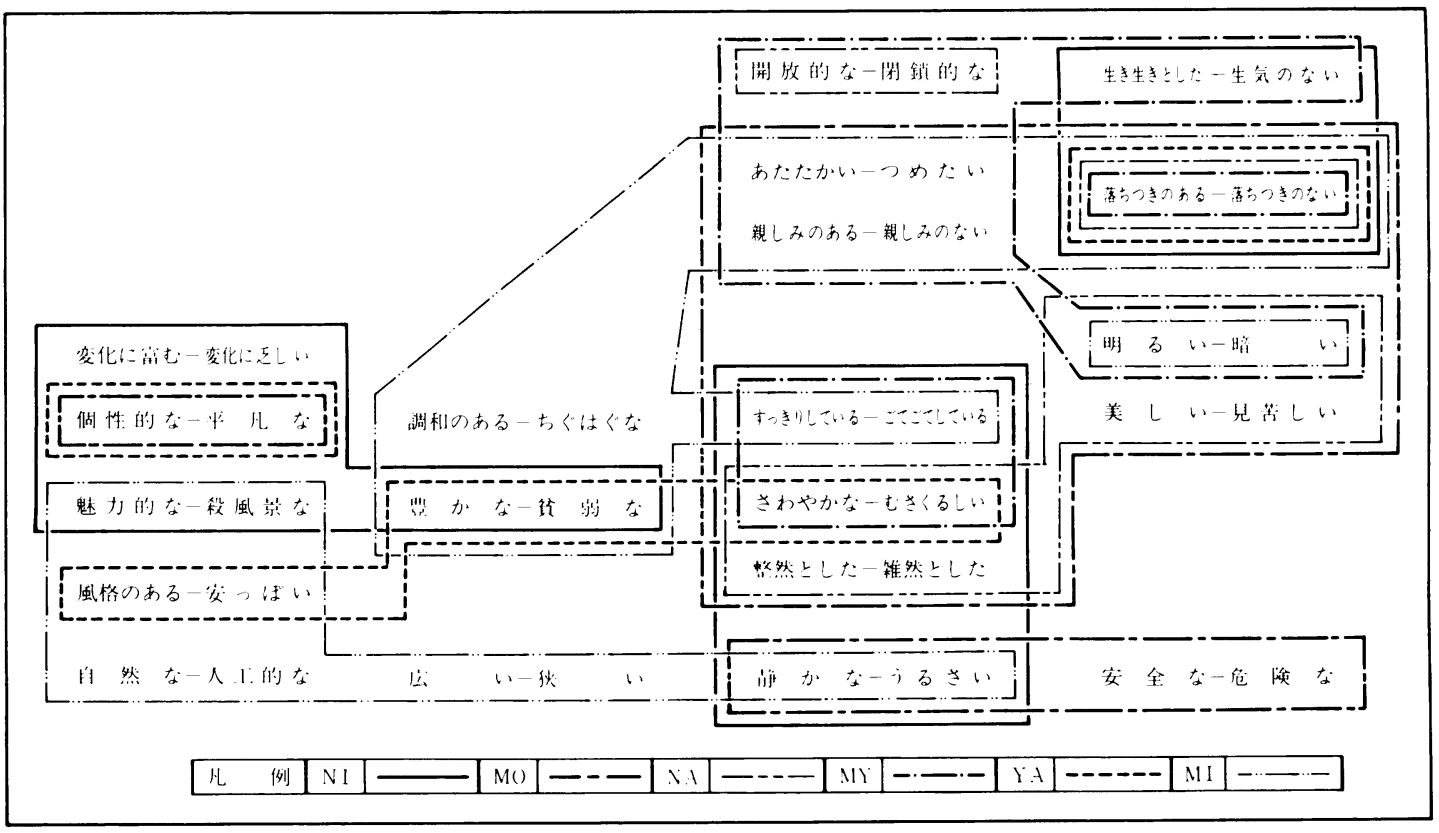

図ー3 情緒的語句からみた街並み景観の意味構造 
緑に係わる項目（緑の量, 専用庭の緑, 共用庭の緑）の 評価が高いととが特徵的である。次に評価の高い要素は, 広場や園路の色・素材, 建物の形等である。一方, 施設 亿係わるファニチャー, 電柱・架線, 車道等の関与度は 相対的に低い。乙こで有意差検定結果をみると，以上の 景観構成要素には, 住宅地間での有意差はみられない。 住宅地間で有意差のみられる景観構成要素は, 屋根の 色・素材, テラスやバルコニーの緑, 駐車場, 照明の 4 要素である。乙れらの景観構成要素の有意差の原因は, “屋根の色・素材”では名谷16団地（MY）のよく目立 つ朱色の瓦屋根, “テラスやバルコニーの緑”では山田 西 $A$ 団地 (YA), 名谷28団地（M I ) で所々に草花の 植鉢がみられるてとに起因していると推測される。また “駐車場”では駐車場の配置形式の違い, “照明”では 色・素材・デザインの違い等に, 住宅地間での有意差が 起因していると推測される。

(2) 景観構成要素に対する認識構造

図-4は, 図-3 と同様の方法で住宅地別の景観構成 要素のグループを総合的に表現したものである。こてで 各住宅地での第 3 合成变量までの累積寄与率は約 30 ～ 60 $\%$ 前後 $(\mathrm{N} \mathrm{I}-66 \%, \mathrm{MO}-63 \%, \mathrm{NA}-34 \%, \mathrm{MY}-$ $38 \%, Y A-50 \%, M ~ I-61 \%)$ で, 住宅地間で隔差が みられる注2)。な打, 各住宅地と屯第 1 ～第 3 合成変量の 固有値は 1.0 以上である。

景観構成要素に対する認識構造の全体的傾向としては, まず緑に係わる有機的要素のグループ（緑の量, 専用庭 の緑, 共用庭の緑) とその他のグループが認識できる。 その他のグループをみると, 建物に係わるグループと施
設に係わるグループの 2 グループに分けられる。さらに 建物に係わるグループをみると, この中であ団地構成に 係わる要素 (住棟配置, 地形, 建物の高さ) のグループ 化が認識できる。住宅地別に景観構成要素に対する認識 構造をみると, 以下の如くである。

庭代台タウン八ウス（N I ）では, 団地構成・建物に 係わる 9 項目, 施設に係わる 6 項目, 緑に係わる 3 項目 がそれぞれ同一グループを形成した。てのととは, 当住 宅地の構成イメージの明確さを示している。桃山台タウ ンハウス（MO）では, 建物・施設に係わる項目, 建物 ・緑施設に係わる項目がそれぞれ同一グループを形成し た。このととは, 当住宅地の諸景観構成要素が相互依存 的関係をむって街並み影観関与していることを示して いる。サニータウン長野台 (NA), 名谷16団地 (MY) では, 第 3 合成変量までの累積寄与率が低く, 諸項目が 独立的変動を示す傾向にある。またNAでは, 緑に係わ る項目のグループ化がみられないととが特徽的である。 山田西A団地（Y A）では，テラスやバルコニーの緑が 緑の量, 共用庭の緑, 専用庭の緑等と同一グループを形 成しており, テラスやバルコニーの緑が他の緑と相乗的 亿緑地環境形成の一役を担っていると推測できる。名谷 28団地（M I ）では, 建物・施設に係わる 7 項目, 団地 構成に係わる 3 項目, 緑・建物に係わる 4 項目がそれぞ れ同一グループを形成した。とのととは，建物と施設が 一体的に認識されているとと，緑と壁面の色・素材が街 並み景観の醇成に対して相乗的に関与しているてとを示 すむのと考える。

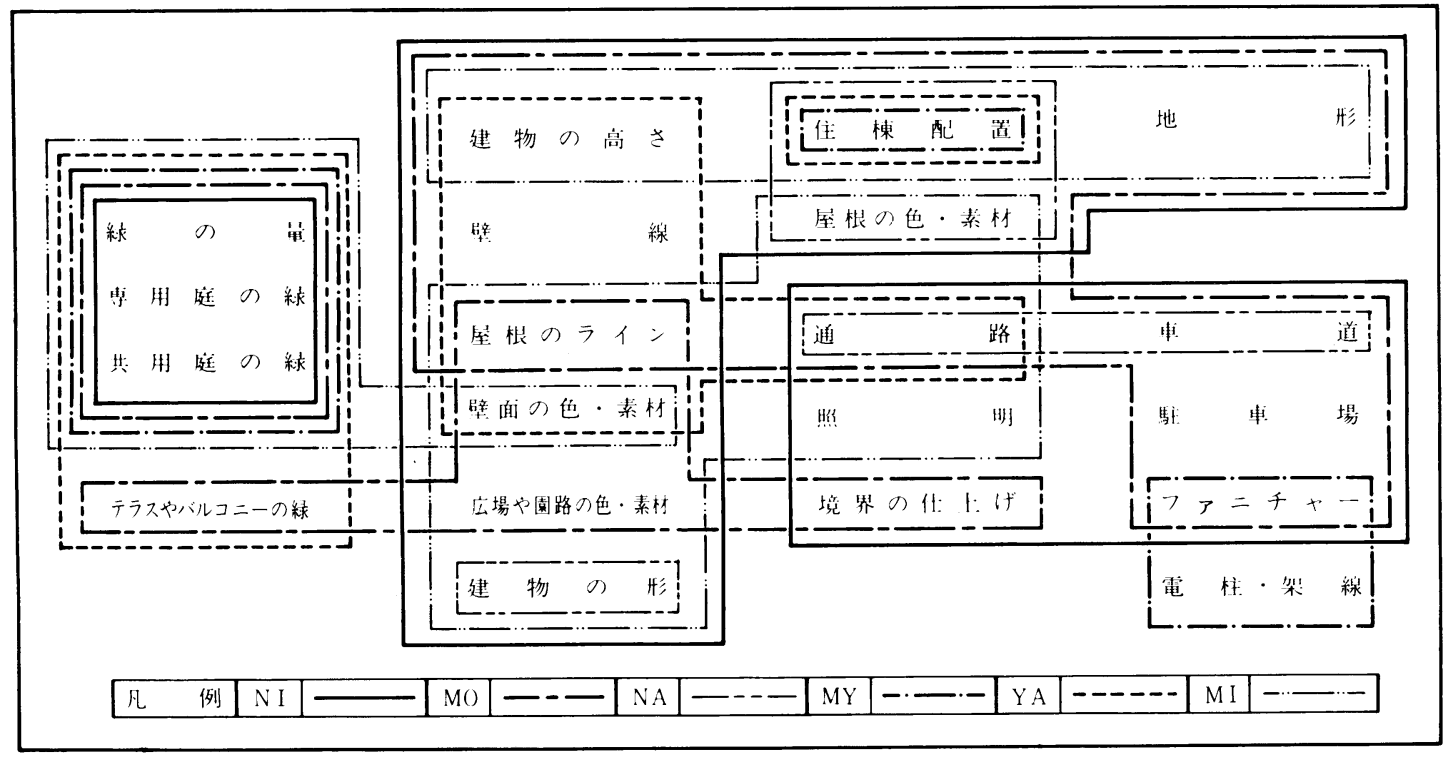

図一４景観構成要素に対する認識構造 
5. 街並み景観の意味構造と景観構成要素との関連性

こてでは, 街並み景観の情緒的意味と景観構成要素と が，居住者の意識の中でどのようなつながりを持ってい るかを検討した結果について述べる。

両者の関連性の解析にあたっては，まず住宅地別に情 緒的語句及び景観構成要素に対する反応データの相関係 数の検定（有意水準 0.05 )を行なった。次に 6 住宅地を 通じてどのような情緒的語句と景観構成要素との間に係 わりがありそうかを把握するために，6住宅地の結果を オーバーラップし，その際の出現頻度（住宅地数）を係 わり合いの強さと定義した。さらに，情緒的語句と景観 構成要素との 1 対 1 の対応関係を, 先に行なった直接バ リマックス法による解析結果をもとに, グループ（情緒 的語句）対グループ（景観構成要素）の対応関係をも含 めて表現した (図 -5 参照)。乙こで図ー 5 亿示す情緒
的語句及び景観構成要素の樹形図は， 6 住宅地での直接 バリマックス法による解析結果に基づき, 同一合成変量 の構造ベクトルの要素で絶対値 0.55 以上の情緒的語句 及び景観構成要素の組み合わせの出現頻度より算出した。 つまり，乙の出現頻度を情緒的語句及び景観構成要素間 の類似度としてとらえ, クラスター分析（可変法）によ り算出したあのである。乙の分析結果は, 図一 3,4 亿 示す総合的な認識構造に対して，6住宅地の全体的傾向 をより明瞭に示しているといえる。以下街並み景観の情 緒的意味と景観構成要素之の係わり合いについて述べる。

情緒的語句及び景観構成要素の中で，それぞれ他方に 対して係わり合いの強い語句及び要素としては，“さわ やかなーむさくるしい”，“魅力的な一殺風景な”ど緑 の量”，“共用庭の緑”が認識できる。また, 電柱・架 線, 駐車場等は, 情緒的語句に対して弱い負の係わりを

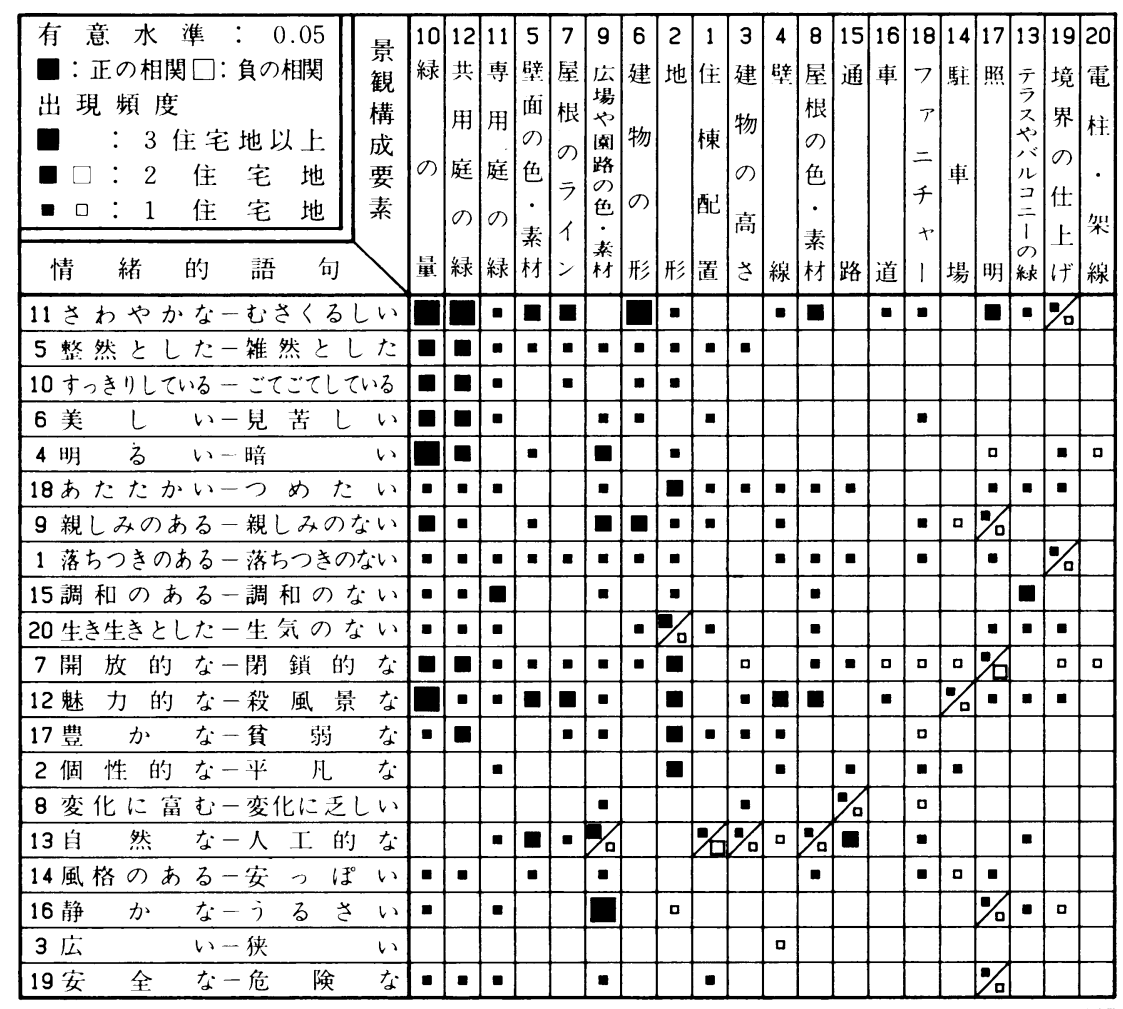

情緒的語们間の 関連性

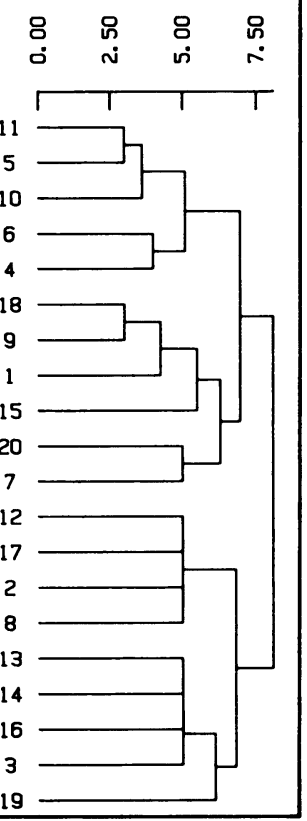

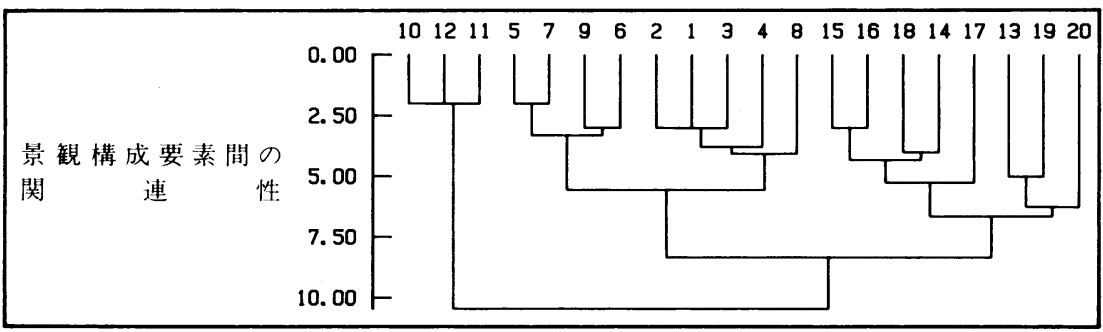

図一 5 街並み景観の意味構造と景観構成要素との関連性 
持つ要素として認識できる。景観構成要素のグループ毎 にみると，緑と建物に係わるグループが，「整然性」

$(11,5,10,6,4)$ ，「親密性」(18, 9, 1，15，20，17）

「魅力性」(12，7，2，8）等の情緒的語句のグループ と正の係わりが強いことが認識できる。中であ緑に係わ るグループ (特に緑の量, 共用庭の緑) では,「整然性」 との正の係わりが強い。また建物に係わるグループに属 する景観構成要素の中では,「整然性」に対して建物の形, 「親密性」に対して地形, 広場や園路の色・素材, 「魅 力性」に対して地形, 壁線等の要素が強い正の係わりを 持っている。以上のことは, 緑や構造物の形態, 色・素 材等の景観構成要素が, 街並み景観の情緒的意味の形成 に係わりか深い要素であるととを示唆している。

\section{6. おわりに}

以上の分析, 考察を通じて, 街亚み景観に対する居住 者の認識構造には, 以下のような基礎的構造が見い出さ れた。

街並み景観の共通的意味構造としては, 居住者は街並 み景観を比較的良好な状態として受け止めているてとが 認識できた。また「魅力性」,「親密性」,「整然性」の 3 軸が, 街並み景観の基礎的意味構造として認識できた。 しかし, 本研究で設定した情緒的語句の約半数に対して 住宅地間で有意差がみられたことは, 街並み景観の意味 構造の把握に際して, 各住宅地の個別的意味（固有性） の重要性が示唆されていると推測できる。

景観構成要素に対する認識構造としては, 緑や構造物 の形態, 色・素材等が, 街並み景観に強く関与している ことが認識できた。また緑関係, 建物関係, 施設関係の 3 グループが, 街並み景観に対する基礎的認識構造とし て把握できた。

街並み景観の意味構造と景観構成要素之の関連性につ いては,「魅力性」,「親密性」,「整然性」等の意味構 造と緑関係, 建物関係の景観構成要素グループとの正の
係わりが強いことが認識できた。特に, 街並み景観に対 する関与度が高い緑や構造物の形態, 色・素材等が, 街 並み景観の意味構造の形成に係わりが強い要素であると いうことは，注目すべき知見であると考える。

本研究では, インタビュー調査をもとに, 低層集合住 宅地の街並み景観に対する居住者の認識構造に関して有 益な示唆を得た。今後ての結果をあとに, 街並み景観計 画に対する具体的な指針作成のための研究が必要である と考える。

最後に, 本研究は住宅・都市整備公団関西支社ならび に当研究室の大学院生, 学部生の協力を得ているととを 書き加えて扰きたい。

\section{参考文献及び注}

1）久保貞他（1982）：低層集合住宅地の景観計画に関 する研究：造園雑誌 VOL.46, No 5

2）久保貞他 (1982)：低層集合住宅地の外部空間設計 亿関する研究：住宅・都市整備公団

3）芝祐順（1972）：相関分析法：東京大学出版会

4）芝祐順（1981）：統計的方法 III：新曜社

5）脇本和昌他（1982）：多変量グラフ解析法：朝倉書 店

注 1) 低層集合住宅地に㧍ける良好な“街並み景観”は， 居住者の反応行動を考慮しつつ, 公的領域と私的領 域の有機的関係の中で計画される必要があると考え る。

したがって, とこでいう“街並み景観”とは, 住 宅地内に存在する建物, 園路, 広場, 緑等の諸物理 的要素の形態, 意匠が, 相互依存的関係をむって構 築する影観のととをいう。

注 2) 第 3 軸までの累積寄与率の低さは，情緒的語句, 景観構成要素の抽出項目にも関係していると考えら れる。

Summary : This study intends to discuss the cognition of resident for landscape in low rise housing. We selected six low rise housing development in Kansai area as case study. The study produced the following findings:

1) The residents' attitude towards landscape desirability was somewhat positive.

2) It was clarifyed that residents' cognition for landscape consisted of three meanings, attractiveness, familiarity, and order.

3) Plants, color, and form of structure in housing environment were concerned in residents' cognition for landscape. 